\title{
Erratum to: New Dimeric and seco-Abietane Diterpenoids from Salvia wardii
}

\author{
Qiu-Li Xiao $\cdot$ Fan Xia $\cdot$ Xing-Wei Yang • \\ Yang Liao $\cdot$ Li-Xin Yang $\cdot$ Yu-Kun Wei \\ Xian Li • Gang Xu
}

Published online: 30 May 2015

(C) The Author(s) 2015. This article is published with open access at Springerlink.com

Erratum to: Nat. Prod. Bioprospect. (2015) 5:77-82

\section{DOI 10.1007/s13659-015-0054-6}

In the HTML version of the original publication, the graphical abstract was inadvertently omitted. The graphical abstract is given in this erratum.

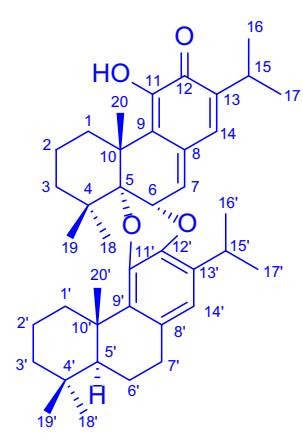

1

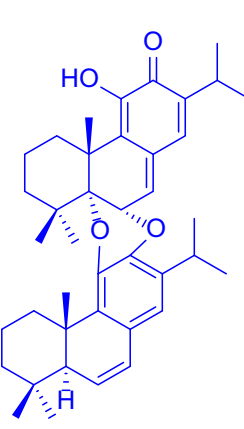

2<smiles>C=C(C)C1CCc2c(C)ccc3cc(C(C)P)c(O)c(c23)O1</smiles>

3<smiles>COc1c2c3c4c(c1C(C)C)CCC4=CCC3OC(C)(C)CC2</smiles>

4<smiles>CC(C)=CC1Cc2c(S)ccc3cc(C(C)C)c(O)c(c23)C1</smiles>

5<smiles>Cc1ccc2c3c1C=CC1C3C(=C(C(C)C)C2=O)OC1(C)C</smiles>

6<smiles>Cc1ccc2c3c1CCCC(C)(C)C3(O)C(=O)C(C(C)C)=C2</smiles>

7<smiles>CC(C)c1cc2c(cc1O)[C@]1(C)CCCC(C)(C)[C@H]1CC2</smiles>

8
The online version of the original article can be found under doi:10.1007/s13659-015-0054-6.

Q.-L. Xiao · F. Xia · X. Li (ه)

School of Pharmaceutical Science and Yunnan Key Laboratory of Pharmacology of Natural Products, Kunming Medical University, Kunming 650500, Yunnan, People's Republic of China

e-mail: xianlikm@163.com

X.-W. Yang · Y. Liao - L.-X. Yang · G. Xu

State Key Laboratory of Phytochemistry and Plant Resources in West China, Kunming Institute of Botany, Chinese Academy of Sciences, Kunming 650201, People's Republic of China e-mail: xugang008@mail.kib.ac.cn

Y.-K. Wei

Shanghai Chenshan Plant Science Research Center, Chinese Academy of Sciences, Beijing, People's Republic of China
Open Access This article is distributed under the terms of the Creative Commons Attribution 4.0 International License (http:// creativecommons.org/licenses/by/4.0/), which permits unrestricted use, distribution, and reproduction in any medium, provided you give appropriate credit to the original author(s) and the source, provide a link to the Creative Commons license, and indicate if changes were made. 